Scientific Journal Warsaw University of Life Sciences - SGGW

Problems of World Agriculture volume 17 (XXXII), number 4, 2017: 218-227

DOI: 10.22630/PRS.2017.17.4.98

\author{
Malgorzata Matyja ${ }^{1}$ \\ Wrocław University of Economics
}

\title{
A Comparative Study of Profitability of Agricultural Cooperatives in Poland and Around the World
}

\begin{abstract}
The differences in perception and functioning of agricultural cooperatives in different parts of the world are visible to the naked eye. Moreover, the literature brings different findings in respect to comparisons between cooperatives and non-cooperatives in terms of profitability. The purpose of this article was to identify the differences in profitability between agricultural cooperatives in selected parts of the world as well as between cooperatives and other enterprises in Polish agriculture. The description of results of the world report on cooperatives and analysis of variance on 300 agricultural enterprises in Poland were used in order to accomplish the above purpose. The main findings prove that American agricultural cooperatives achieved the best profitability results and that cooperatives have lower profitability than other enterprises in agriculture.
\end{abstract}

Key words: agricultural cooperatives, profitability, analysis of variance, Kruskal-Wallis test, Poland

JEL Classification: M21, Q12, Q13

\section{Introduction}

For many years cooperatives have been an interesting alternative of doing business and simultaneously an important element of socio-economic life all over the world. In the agricultural sector they play a prominent role, both in developed and developing countries (Tortia et al., 2013). The world's largest agricultural cooperatives, with annual turnover of more than 40 billion USD, are located in Asia and North America (World..., 2016). In Canada cooperatives have large market shares in grain, dairy products, poultry, honey and maple (Hudson, 2009). Many agricultural cooperatives operate in India and China where the small size of land holdings fosters working together to gain economies of scale and scope (Measuring..., 2014). In Africa cooperatives are significantly contributing to poverty reduction, especially in rural areas (Wanayama et al., 2008).

In Western Europe cooperatives hold a strong position on agricultural markets and continue to develop their expanded structures (Suchoń, 2012). They have evolved into modern forms of economic activity, strengthening the bargaining power of their members (Mierzwa, 2009). In countries such as Finland, the Netherlands, Denmark, Sweden, Ireland, France and Austria, the share of cooperatives in the agricultural market counts to $50-70 \%$ (Bijman et al., 2012). Firms such as Arla Foods, Danish Crown and DMK Deutsches Milchkontor $\mathrm{GmbH}$, with their annual revenues of 5-10 billion EUR, stand among the largest and best-known agricultural cooperatives in Europe (Development..., 2015). This brief description of the strength of agricultural cooperatives demonstrates that, globally, agricultural cooperatives use their potential and continue to develop.

However, there are some countries where cooperatives, instead of developing, successively cease their activity. This refers particularly to post-communist countries, like

${ }^{1}$ PhD Eng., Komandorska Str. 118/120, 53-245 Wrocław, e-mail: malgorzata.matyja@ue.wroc.pl 
Poland, where cooperatives are regarded as a relic of the previous regime with all the economic, political, legal and social consequences (Dzun, 2009). The lack of a comprehensive theoretical framework and an in-depth analysis in this subject even worsens the situation (INT.RE.COOP Report Summary, 2016).

Because the differences in perception and functioning of agricultural cooperatives in different parts of the world are visible to the naked eye, from the scientific point of view it is justified to make the comparisons of different aspects of cooperative life. One of the most important issues that has to be taken into account while comparing economic entities, is financial performance and one of its measures: profitability (Fitzsimmons et al., 2005). Moreover, it turns out that under the same economic conditions, some cooperatives show great development dynamics, some of them are characterized by stagnation and others are in recession (Mierzwa, 2013). Therefore, the comparisons between cooperatives and other enterprises are also scientifically interesting. In this light, the purpose of this article is to identify the differences in profitability between agricultural cooperatives in selected parts of the world as well as between cooperatives and other enterprises in Polish agriculture.

\section{A Literature Overview}

Regarding profitability, there are studies which consider it to be an indicator of a company's growth, success and control (Majed et al., 2012). Some authors use it as a measure of competitiveness in agriculture (Korom \& Sagi, 2005) or even of a firm's overall efficiency (Bumbescu, 2015). The well-known ratios of profitability are return on assets - ROA, return on equity - ROE and return on sales - ROS (Machek, 2014). They help to evaluate a business's ability to generate earnings compared to its expenses incurred over a period of time. Profitability is the synthetic determinant of financial standing, which fundamentally influences the assessment of competitive ability, and thus the ability to continue agricultural activity and development prospects (Gołaś, 2009).

Nevertheless, while analyzing the profitability of agricultural cooperatives one has to be aware of the specificity of such entities. Sexton and Iskow (1988) demonstrated how financial analyses of cooperatives, although popular, were not based on economic theory. This results from the objective of cooperatives: to maximize the benefits and welfare of their members and the local community. According to the literature, cooperatives do not only seek to maximize profits, but they also seek to satisfy the interests of their members by increasing the prices of their products as much as possible (Guzmán and Arcas, 2008; Soboh et al., 2009, 2012; Hernández et al., 2013). As a consequence, cooperatives are expected to have a low profitability level (Martínez-Victoria et al., 2015).

Some studies confirm the above statement (Notta and Vlachvei, 2007; Soboh et al., 2011). The authors conclude that cooperatives have lower profitability values than noncooperatives because they increase the cost of the purchased products to their memberssuppliers by paying out parts of their profit in the price. On the other hand, there are also studies which prove that profitability of agricultural cooperatives and other enterprises is similar (Lermand and Parliament, 1990; Gentzoglanis, 1997; Boyle, 2004; Hardesty and Salgia, 2007). Boyle (2004) claims that this is because the cooperatives did not establish their prices at the maximum value as non-cooperatives companies do. Hardesty and Salgia (2004) explain it with the characteristics of each industry (dairy, fruit and vegetables, grain, farm supply), where cooperatives and non-cooperatives operate. In the view of such diverse 
research results, there is the need for further investigation of the differences in profitability of agricultural cooperatives.

\section{Data and Methods}

According to the objective of the present study, two approaches were used: the regional and subjective. The first one referred to searching for differences in profitability of cooperatives in different regions of world agriculture. The second approach included comparisons of profitability between agricultural cooperatives and other enterprises. Special attention was paid to Polish agricultural production cooperatives (APC) as the representatives of agricultural cooperatives in Poland.

The statistical data sources in the article were the following:

- For the regional, and partially subjective approach - the "World Co-operative Monitor" - a robust and comprehensive report published annually by the International Co-operative Alliance and the European Research Institute on Cooperative and Social Enterprises (World..., 2016);

- For the subjective approach - the "List of the 300 Best Agricultural Enterprises" prepared annually by the Institute of Agricultural and Food Economics - the National Research Institute in Poland (Lista..., 2010, 2011, 2012, 2013, 2014, 2015).

The above list includes agricultural enterprises established from the property of the Treasury (former state farms) and agricultural production cooperatives. The source data are collected using a specially designed questionnaire, which is aligned with the official items of financial statements.

In the subjective approach, the study utilizes a sampling frame consisting of the following types of agricultural enterprises: agricultural production cooperatives - APC, companies of state agency (Agricultural Property Agency) - CSA, private companies - PC, the rest of the entities - RE. The profitability in the subject approach of this study consists of five ratios:

- Return on Sales (ROS) - the ratio of profit on sales to the sum of revenues from sales of products, goods and materials. The operating costs, calculated in the profit on sales, include also the labor costs of member-workers of APC;

- Return on usiness (ROB) - the ratio of financial profit from business activity, adjusted for profit (-) or losses (+) from the sale of non-financial assets, to the sum of revenues from sales, other operating income (decreased by profit from disposal of non-financial assets) and financial income;

- Return on Assets (ROA) - the ratio of net financial profit, adjusted for profit (-) or losses (+) from the disposal of non-financial assets, to the value of general assets;

- Return on Equity (ROE) - the ratio of net financial profit, adjusted for profit (-) or losses (+) from the disposal of non-financial assets, to capital equity;

- Value Index (VI) - the ratio of return on equity and the cost of capital equity containing, among others, average interest rates on bank deposits. Only index higher than one means that the value of the enterprise was increased for its owners.

The data analysis was done in STATISTICA software. In order to accomplish the objectives of the research, the analysis of variance was used. Because almost all of the variables were not normally distributed there was a need to use the non-parametric methods 
of analysis of variance, which was the Kruskal-Wallis test. This type of analysis is used to determine the influence of one classification factor (controlled on multiple levels) on the results of the study as a result of the comparison between the groups of analyzed units. The following formula of statistical hypotheses was adopted (Stanisz, 2006):

- null hypothesis H0: the averages in the groups are the same;

- alternative hypothesis H1: at least two averages differ between each other.

The process of verifying hypotheses consisted of rejecting the null hypothesis in favor of the adoption of its alternative, taking into account the significance level $\alpha=0,05$. The rejection of the null hypothesis indicated the existence of statistically significant differences between the compared groups. The results of the test were supplemented with graphical interpretation using a box and whisker plots.

\section{Research results}

When it comes to the analysis of the financial indexes of the agricultural cooperatives around the world, it turns out that they are doing quite well (Table 1).

\begin{tabular}{|c|c|c|c|c|c|c|}
\hline Index & Definition & $\begin{array}{l}\text { No. of coops } \\
\text { in the sample }\end{array}$ & In total & $\begin{array}{l}\text { Americas } \\
\text { region }\end{array}$ & $\begin{array}{l}\text { Asia and } \\
\text { the Pacific }\end{array}$ & $\begin{array}{l}\text { European } \\
\text { region }\end{array}$ \\
\hline ROE & net income/total equity & 71 & 10,3 & 19,1 & 6,2 & 8,4 \\
\hline ROA & net income/total assets & 71 & 3,4 & 4,9 & 2,5 & 3,2 \\
\hline Liquidity & $\begin{array}{l}\text { total current assets/total } \\
\text { current liabilities }\end{array}$ & 66 & 1,66 & 1,64 & 2,57 & 1,51 \\
\hline Account $\%$ & $\begin{array}{c}\text { accounts payable/current } \\
\text { liabilities }\end{array}$ & 59 & 62,2 & 44,9 & 66,6 & 66,1 \\
\hline Leverage & long term debt/total equity & 63 & 84 & 90 & 101 & 80 \\
\hline Margin1 & $\begin{array}{c}\text { (total equity - net } \\
\text { property, plant and } \\
\text { equipment)/total equity }\end{array}$ & 68 & $-0,7$ & 10,2 & $-3,9$ & $-3,2$ \\
\hline Margin2 & $\begin{array}{l}\text { (total equity - net } \\
\text { property, plant and } \\
\text { equipment }+ \text { long term } \\
\text { debt)/total equity }\end{array}$ & 62 & 17,1 & 28,2 & 12,9 & 15,2 \\
\hline Net property $\%$ & $\begin{array}{l}\text { net property, plant and } \\
\text { equipment/total equity }\end{array}$ & 68 & 36,9 & 26,1 & 41,3 & 39,1 \\
\hline
\end{tabular}

Source: Author's own study on the basis of (World..., 2016).

The average ROE value is $10,3 \%$. The highest ROE $(19,1 \%)$ shows cooperatives from the region of the Americas (precisely from the USA, Canada and Brazil). This can be the result of a higher net income or a lower level of the total equity. By looking at the ROA, the agricultural cooperatives show also positive results, but not as high as ROE $(3,4 \%$ on average). In this case, the Americas also achieve the best results (4,9\%), however the differences between regions are slighter. The data shows a sector in moderate equilibrium with respect to liquidity, with the best situation in Asia and the Pacific. The cooperative 
regions differ in terms of the accounts payable - the European and Asian co-operatives in the data set perform better compared with those in the Americas region. The financial leverage data does not differ greatly between regions. The cooperatives prefer rather safe strategies of financing. Two additional indexes - Margin1 and Margin2 - are used to determine the ability to cover the fixed assets by long-term liabilities. The higher the Margin2 value - with a not too pronounced negative value of the Margin1 index, the better the financial equilibrium of the co-operative is. The data shows a solid sector, in financial equilibrium with a significant difference between the Americas and European/Asian regions in favor of the former ones. Comparing this with the net property percentage, one can conclude that the greater values of margins indexes achieved by cooperatives in the Americas might be the consequence of a lower level of investments because of a greater use of outsourcing. However, this is only an assumption that requires further verification.

Summing up, the data show the advantage of agricultural cooperatives in the Americas over the rest in terms of profitability and financial solidity. The reasons for this situation can be many, including natural conditions, markets specificities, or even governance abilities. While such considerations are not the subject of this study, the next step is to compare the financial performance of agricultural cooperatives with other sectorial enterprises. Within this scope, the data are shown in Table 2 . They are limited only to the European region.

Table 2. Financial indexes for agricultural enterprises in Europe (\%)

\begin{tabular}{l|cccc}
\hline \multicolumn{1}{c|}{ Index } & $\begin{array}{c}\text { No. of coops in the } \\
\text { sample }\end{array}$ & $\begin{array}{c}\text { Values for } \\
\text { cooperatives }\end{array}$ & $\begin{array}{c}\text { No. of other } \\
\text { enterprises in the } \\
\text { sample }\end{array}$ & $\begin{array}{c}\text { Values for other } \\
\text { enterprises }\end{array}$ \\
\hline liquidity & 45 & 1,5 & 81 & 1,7 \\
account\% & 40 & 66,1 & 77 & 13,3 \\
leverage & 46 & 80,0 & 84 & 67,0 \\
margin1 & 47 & $-3,2$ & 84 & $-15,6$ \\
margin2 & 45 & 15,2 & 84 & 1,8 \\
net property\% & 46 & 39,1 & 84 & 59,7 \\
\hline
\end{tabular}

Source: Author's own study on the basis of (World..., 2016).

The differences between the compared groups are not so significant regarding liquidity and leverage. However, they appear when looking at other indexes. Firstly, the account percentage shows that the cooperatives tend to use suppliers' debt more than other enterprises. Secondly, relatively huge differences refer to margins and net property indicators. Their values confirm that cooperatives are more solid than other firms in the European agriculture.

Switching to the Polish conditions, as it was mentioned before, the profitability of agricultural cooperatives was also measured in comparison to other types of entities. The detailed data on cardinality of the sample are presented in Table 3. In every studied year, the 300 of enterprises were examined. Almost half of them were public companies (PC), approximately one third were agricultural production cooperatives (APC), about $10 \%$ accounted for companies of state agency (CSA), the rest (also 10\%) consisted of other entities (RE), including individual farms. Plant production was the main activity for the 
vast majority of APC and PC. A relatively large share of livestock production was regarded for CSA. The most diverse group in terms of direction of production was RE.

Table 3. The number and percentage of enterprises in the research sample in every analyzed year

\begin{tabular}{|c|c|c|c|c|c|c|c|c|c|}
\hline \multirow{2}{*}{$\begin{array}{l}\text { Type of } \\
\text { entity }\end{array}$} & \multirow{2}{*}{$\begin{array}{l}\text { Direction of } \\
\text { production* }\end{array}$} & \multicolumn{6}{|c|}{ Year } & \multirow{2}{*}{$\begin{array}{c}\text { Average } \\
\text { no. in } \\
\text { 6-year } \\
\text { period }\end{array}$} & \multirow{2}{*}{$\begin{array}{c}\text { Percentage } \\
\text { in each } \\
\text { type of } \\
\text { entity }\end{array}$} \\
\hline & & 2010 & 2011 & 2012 & 2013 & 2014 & 2015 & & \\
\hline \multirow{5}{*}{ APC } & Plant & 46 & 52 & 58 & 58 & 56 & 50 & 53 & $59 \%$ \\
\hline & Livestock & 14 & 11 & 8 & 12 & 13 & 15 & 12 & $13 \%$ \\
\hline & Mixed & 22 & 26 & 21 & 27 & 23 & 26 & 24 & $27 \%$ \\
\hline & Other & 0 & 1 & 0 & 1 & 2 & 4 & 1 & $1 \%$ \\
\hline & In total & 82 & 90 & 87 & 98 & 94 & 95 & 91 & $100 \%$ \\
\hline \multirow{5}{*}{ CSA } & Plant & 12 & 10 & 11 & 9 & 12 & 11 & 11 & $27 \%$ \\
\hline & Livestock & 16 & 15 & 12 & 12 & 13 & 13 & 14 & $34 \%$ \\
\hline & Mixed & 12 & 16 & 15 & 15 & 16 & 17 & 15 & $38 \%$ \\
\hline & Other & 0 & 0 & 0 & 0 & 0 & 0 & 0 & $0 \%$ \\
\hline & In total & 40 & 41 & 38 & 36 & 41 & 41 & 40 & $100 \%$ \\
\hline \multirow{5}{*}{$\mathrm{PC}$} & Plant & 98 & 90 & 96 & 88 & 94 & 94 & 93 & $68 \%$ \\
\hline & Livestock & 8 & 8 & 10 & 13 & 10 & 8 & 10 & $7 \%$ \\
\hline & Mixed & 39 & 36 & 32 & 26 & 26 & 26 & 31 & $22 \%$ \\
\hline & Other & 5 & 6 & 3 & 4 & 2 & 4 & 4 & $3 \%$ \\
\hline & In total & 150 & 140 & 141 & 131 & 132 & 132 & 138 & $100 \%$ \\
\hline \multirow{5}{*}{ RE } & Plant & 12 & 12 & 13 & 11 & 10 & 12 & 12 & $37 \%$ \\
\hline & Livestock & 4 & 7 & 7 & 10 & 9 & 9 & 8 & $24 \%$ \\
\hline & Mixed & 8 & 7 & 8 & 7 & 6 & 6 & 7 & $22 \%$ \\
\hline & Other & 4 & 3 & 6 & 7 & 8 & 5 & 6 & $17 \%$ \\
\hline & In total & 28 & 29 & 34 & 35 & 33 & 32 & 32 & $100 \%$ \\
\hline \multicolumn{2}{|c|}{ All of the entities } & 300 & 300 & 300 & 300 & 300 & 300 & $\sim 300$ & \\
\hline
\end{tabular}

* Direction of production was declared by the respondents on the basis of predominant share of sales. "Mixed" means that there is an equilibrium of plant and livestock production. "Other" means that the agricultural production is just an addition to the other economic activity.

Source: Author's own study on the basis of (Lista..., 2010, 2011, 2012, 2013, 2014, 2015).

As a result of data analysis done by using the Kruskal-Wallis test, it was found that statistically significant differences exist between the profitability of agricultural cooperatives and other Polish agricultural enterprises. This refers mainly to public companies, which showed higher values of medians for each of the indexes in each year. Similar conclusions can be drawn while comparing APC to the RE - the cooperatives had lower profitability of all indexes in 2010 and 2013-2015 (with a little exception of VI in 2015). However, the APC do not differ from CSA in terms of profitability as the identified differences within this scope were sporadic and irregular. The detailed findings are presented in Table 4, enriched with Figure 1. 

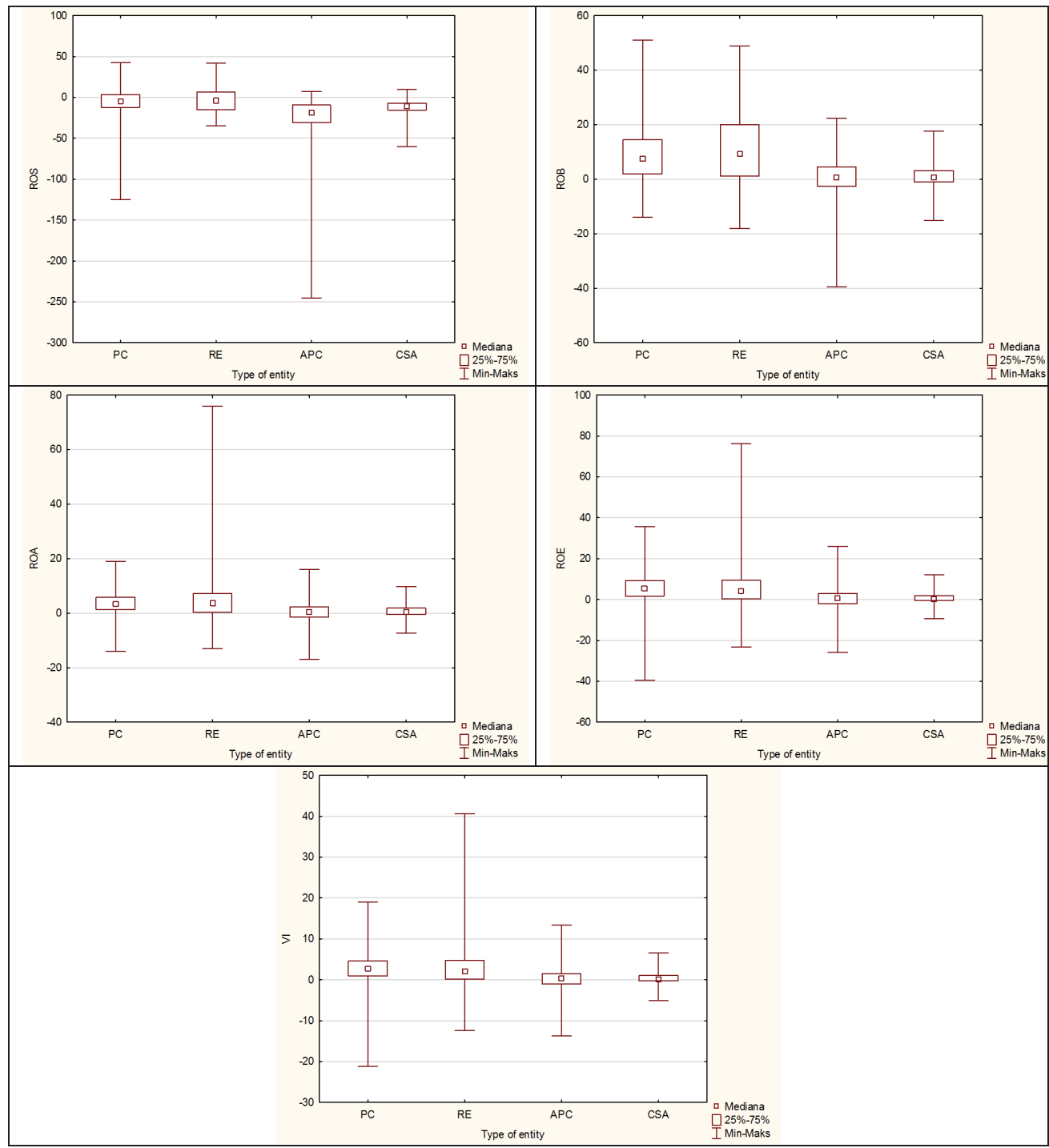

Fig. 1. Box and whisker plots for each of profitability indexes of analyzed typed of entities Source: Author's own study on the basis of the research results. 
Table 4. The results of the Kruskal-Wallis test with the p-values and the medians of APC in comparison to other entities

\begin{tabular}{|c|c|c|c|c|c|c|c|c|c|c|c|c|c|}
\hline \multirow{2}{*}{ 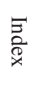 } & \multirow{2}{*}{$\begin{array}{l}\text { Type } \\
\text { of } \\
\text { entity }\end{array}$} & \multicolumn{2}{|c|}{2010} & \multicolumn{2}{|c|}{2011} & \multicolumn{2}{|c|}{2012} & \multicolumn{2}{|c|}{2013} & \multicolumn{2}{|c|}{2014} & \multicolumn{2}{|c|}{2015} \\
\hline & & $\mathrm{p}$ & $\mathrm{m}$ & $\mathrm{p}$ & $\mathrm{m}$ & $\mathrm{p}$ & $\mathrm{m}$ & $\mathrm{p}$ & $\mathrm{m}$ & $\mathrm{p}$ & $\mathrm{m}$ & $\mathrm{p}$ & $\mathrm{m}$ \\
\hline \multirow{3}{*}{ రె̈ } & CSA & 1,000000 & na & 0,584968 & na & 0,036636 & hig & 1,000000 & na & 0,148435 & na & 0,017018 & lo \\
\hline & $\mathrm{PC}$ & 0,000000 & lo & 0,254789 & na & 0,001128 & lo & 0,000004 & lo & 0,000000 & lo & 0,000000 & lo \\
\hline & $\mathrm{RE}$ & 0,000064 & lo & 1,000000 & na & 1,000000 & na & 0,002014 & lo & 0,000043 & lo & 0,000003 & lo \\
\hline \multirow{3}{*}{ こొ } & CSA & 0,210482 & na & 0,063348 & na & 0,001147 & hi & 1,000000 & na & 1,000000 & na & 1,000000 & na \\
\hline & $\mathrm{PC}$ & 0,000000 & lo & 0,000461 & lo & 0,000680 & lo & 0,000003 & lo & 0,000000 & lo & 0,000000 & lo \\
\hline & $\mathrm{RE}$ & 0,000461 & lo & 0,191538 & na & 1,000000 & na & 0,000025 & lo & 0,000053 & lo & 0,000065 & lo \\
\hline \multirow{3}{*}{$\begin{array}{l}\pi \\
0 \\
0\end{array}$} & CSA & 0,118257 & na & 0,084978 & na & 0,000391 & hi & 1,000000 & na & 1,000000 & na & 1,000000 & na \\
\hline & PC & 0,000000 & lo & 0,000003 & lo & 0,000007 & lo & 0,000017 & lo & 0,000000 & lo & 0,000000 & lo \\
\hline & $\mathrm{RE}$ & 0,010697 & lo & 0,962825 & na & 1,000000 & na & 0,001615 & lo & 0,003052 & lo & 0,000581 & lo \\
\hline \multirow{3}{*}{ 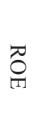 } & CSA & 0,044220 & hi & 0,014353 & hi & 0,000172 & hi & 0,722342 & na & 1,000000 & na & 1,000000 & na \\
\hline & $\mathrm{PC}$ & 0,000000 & lo & 0,000000 & lo & 0,000000 & lo & 0,000005 & lo & 0,000000 & lo & 0,000000 & lo \\
\hline & RE & 0,019090 & lo & 1,000000 & na & 1,000000 & na & 0,020671 & lo & 0,011161 & lo & 0,005113 & lo \\
\hline \multirow{3}{*}{$\leq$} & CSA & 0,042690 & hi & 0,012934 & hi & 0,000085 & hi & 0,935407 & na & 1,000000 & na & 0,003605 & na \\
\hline & $\mathrm{PC}$ & 0,000000 & lo & 0,000004 & lo & 0,000001 & lo & 0,000014 & lo & 0,000000 & lo & 0,000000 & lo \\
\hline & RE & 0,026615 & lo & 1,000000 & na & 1,000000 & na & 0,011556 & lo & 0,013553 & lo & 1,000000 & lo \\
\hline
\end{tabular}

$\mathrm{p}-\mathrm{p}$-values,

$\mathrm{m}-$ median,

na- not applicable,

lo-lower,

hi - higher.

Source: Author's own study on the basis of the research results.

\section{Conclusion}

While considering profitability of agricultural cooperatives, what has to be taken into account is that these types of enterprises are not profit-oriented. They exist in order to maximize the benefits for their members. Thus, in the model of cooperating with farmermembers, dominating worldwide, agricultural cooperatives give farmers higher, satisfying prices for supplied products, thereby decreasing the general profits. In return, in the model of worker cooperatives, such as Polish agricultural production cooperatives, the profit is decreased by the labor costs of member-workers, the level of which should also be satisfying. Therefore, as was stated in the article, agricultural cooperatives are expected to have a low profitability.

The analysis of profitability and financial solidity in the regional approach revealed that the best results are achieved by agricultural cooperatives in the Americas. European cooperatives perform better than other sectorial enterprises regarding margins and net property. However, the evidence of comparison between cooperatives and non-cooperatives 
from Poland showed that there are statistically significant differences regarding the profitability. Entities like private companies or even individual farms reach higher levels of profitability indicators (ROS, ROB, ROA, ROE, VI). Thus, the obtained results confirm the findings of Notta and Vlachvei (2007) and Soboh et al. (2011). They also fall into the expectations about cooperatives' lower profitability suggested by Martínez-Victoria et al. (2015). Nevertheless, the analysis should be enriched with comparisons of purchase prices of agricultural products and wages in agriculture to properly verify this statement. Otherwise, the low profitability could be the result only of inefficient management of the cooperative.

Finally, it has to be noticed that the profitability in agriculture can be connected with the direction of production. The vast majority of studied enterprises in Poland were oriented to plant production. A quick look at the results of the analysis enables to say that enterprises like CSA, with a relatively big share of livestock production, in general achieved lower profitability indexes. Therefore, this side of analysis needs also to be examined more thoroughly.

\section{References}

Bijman, J., Iliopoulos, C., Poppe, K., Gijselinckx, C., Hagedorn, K., Hanisch, M., Hendrikse, G.W.J., Kuhl, R., Ollila, P., Pyykkonen, P., Sangen, G. (2012). Support for Farmer's Cooperatives, Brussels: EC, 30.

Boyle, G.E. (2004). The economic efficiency of Irish dairy marketing cooperatives. Agribusiness, 20(2), 143-153.

Bumbescu, S.S. (2015). Performance analysis in agriculture using Du Pont model. Sibiu Alma Mater University Journals, Series A. Economic Sciences, 8(2), 41-47.

Development of Agricultural Cooperatives in the EU 2014 (2015). Brussels: Copa-Cogeca, 24.

Dzun, W. (2009). Spółdzielnie produkcji rolnej w procesie przemian systemowych. Zagadnienia Ekonomiki Rolnej, 4, 67-89.

Fitzsimmons, J.R., Steffens, P.R., Douglas, E.J. (2005). Growth and Profitability in Small and Medium Sized Australian Firms, Melbourne: AGSE Entrepreneurship Exchange, 3.

Gentzoglanis, A. (1997). Economic and financial performance of cooperatives and investor-owned firms: an empirical study. Nilsson, J., Van Dijk, G. (eds), Strategies and Structures in the Agro-Food Industries. Assen: Van Gorcum and Comp, 171-183.

Gołaś, Z. (2009). Analiza rentowności kapitału w rolnictwie. Journal of Agribusiness and Rural Development, $1(11), 63-74$.

Guzmán, I., Arcas, N. (2008). The usefulness of accounting information in the measurement of technical efficiency in agricultural cooperatives. Annals of Public and Cooperative Economics, 79 (1), 107-131.

Hardesty, S.D., Salgia, V.D. (2007). Most West Coast agricultural cooperatives are financially competitive. California Agriculture, 61(4), 172-176.

Hernandez-Espallardo, M., Arcas-Lario, N., Marcos-Matás, G. (2013). Farmers' satisfaction and intention to continue membership in agricultural marketing cooperatives: neoclassical versus transaction cost considerations. European Review of Agricultural Economics, 40(2), 239-260.

Hudson, R.J. (ed.). (2009) Management of Agricultural, Forestry and Fisheries Enterprises. Singapore: Eolss Publishers, 75.

INT.RE.COOP Report Summary (2016). European Union. Accessed 30 May 2017 from: http://cordis.europa.eu/ result/rcn/177490_en.html.

Korom, E., Sagi, J. (2005). Measures of competitiveness in agriculture. Journal of Central European Agriculture, 6(3), 375-380.

Lerman, Z., Parliament, C. (1991). Size and industry effects in the performance of agricultural cooperatives. Agricultural Economics, 6(1), 15-29.

Lista 300 najlepszych przedsiębiorstw rolnych $(2010,2011,2012,2013,2014,2015)$. Instytut Ekonomiki Rolnictwa i Gospodarki Żywnościowej - Państwowy Instytut Badawczy. Accessed 16 May 2017 from: http://www.ierigz.waw.pl/prace-badawcze/ranking-300.

Machek, O. (2014). The relationship between financial performance and total factor productivity: evidence from the Czech agricultural sector. International Journal of Social Sciences And Humanity Studies, 6(2), 57-67. 
Kabajeh, M.A.M, Al Nuaimat, S.M.A., Dahmash, F.N. (2012). The Relationship between the ROA, ROE and ROI Ratios with Jordanian Insurance Public Companies Market Share Prices. International Journal of Humanities and Social Science, 2(11), 115-120.

Martínez-Victoria, M.C., Arcas-Lario, N., Maté-Sánchez-Val, M.L. (2015). Comparison of the Financial Behaviour of Agri-Food Cooperatives with Non-Cooperatives from a Static and Dynamic Perspective: an Empirical Application to Spanish Companies, Cartagena: Comunicaciones Presentadas - Actas del XVIII Congreso AECA, 6.

Measuring the Size and Scope of the Cooperative Economy: Results of the 2014 Global Census on Co-operatives (2014). Madison: United Nation.

Mierzwa, D. (2009). Przedsiębiorstwo spółdzielcze - dotychczasowe doświadczenia i kierunki rozwoju. Roczniki Nauk Rolniczych, Seria G, 96(3), 293-301.

Mierzwa, D. (2013). Ocena ekonomiczno-społecznych efektów tradycyjnego sposobu zarządzania spółdzielniami rolniczymi. Roczniki Ekonomii Rolnictwa i Rozwoju Obszarów Wiejskich, 100(1), 227-238.

Notta, O., Vlachvei., A. (2007). Performance of Cooperatives and Investor-Owned Firms: The Case of the Greek Dairy Industry. Karantininis, K., Nilsson, J. (eds), Vertical Markets and Cooperative Hierarchies The Role of Cooperatives in the Agri-Food Industry. Dordrecht: Springer Academic Publishers, 277-287.

Sexton, R.J., Iskow, J. (1988). Factors Critical to the Success or Failure of Emerging Agricultural Cooperatives. Giannini Foundation Info Series, No 88-3, 25.

Soboh, R., Lansink, A., Giensen, G., Van Djik, G. (2009). Performance measurement of the agricultural marketing cooperatives: The gap between theory and practice. Review of Agricultural Economics, 31(3), 446-469.

Soboh, R., Lansink, A., Van Dijk, G. (2011). Distinguishing dairy cooperatives from investor-owned firms in Europe using financial indicators. Agribusiness, 27(1), 34-46.

Soboh, R., Lansink, A., Van Dijk, G. (2012). Efficiency of cooperatives and investor-owned firms revisited. Journal of Agricultural Economics, 63 (1), 142-157.

Stanisz, A. (2006). Przystępny kurs statystyki z zastosowaniem STATISTICA PL na przykładach z medycyny, T. 1., Kraków: Statsoft Polska, 197.

Suchoń, A. (2012). Spółdzielnie w rolnictwie w wybranych Państwach Europy Zachodniej; aspekty prawne i ekonomiczne. Zeszyty Naukowe SGGW Problemy Rolnictwa Światowego, 12(2), 94-103.

Tortia, E., Valentinov, V., Iliopoulos, C. (2013). Agricultural cooperatives. Journal of Entrepreneurial and Organizational Diversity, 2(1), 23-36.

Wanayama, F.O., Develtere, P., Pollet, I. (2008). Encountering the Evidence: Cooperatives and Poverty Reduction in Africa. Working Paper on Social and Co-operative Entrepreneurship, WP-SCE 08.02, 13-14.

World Co-operative Monitor (2016). Exploring the Co-operative Economy, ICA, EURICSE. Accessed 16 May 2017 from: http://monitor.coop/. 